\title{
PENGEMBANGAN PRAKTIKUM DECODER DAN ENCODER MENGGUNAKAN VIRTUAL INSTRUMENT
}

\author{
Nurkahfi irwansyah ${ }^{1}$ \\ ${ }^{1}$ Prodi Teknik Elektro UNPAM \\ Jln. Puspiptek Raya No 46 Buaran, Setu - Tangerang Selatan 15310 \\ dosen01318@unpam.ac.id
}

\begin{abstract}
ABSTRAK
Dalam perkembangan teknologi pengukuran sangatlah penting dalam melakukan berbagai pekerjaan maupun pengumpulan data yang bersifaf objektif. Yang dimana hasil tersebut dapat memiliki keakuratan dan dapat di pertanggung jawabkan hasilnya. Dalam pengukuran tersebut banyak sekali alat yang di pergunakan dalam hal pengukuran yeng tentu saja merepotkan dalam hal efektifitas bekerja tidak hanya banyak namun besar dari ukuran alat menyulitkan untuk di bawa kemanapun dalam beraktifitas. Oleh karena itu pengembangan dalam hal pengukuran sangatlah membantu para pekerja dalam mementukan nilai dari suatu data yang akan di ambil. Terutama alat yang mudah di bawa kemanapun dam memiliki berbagai kemampuan dalam hal pengukuran dengan menggunakan teknologi digital yang di keluarkan oleh Nasional Instrument terciptalah NI myRIO alat yang dapat di program untuk proses pengukuran dan dapat di tampilkan pula ke dalam suatu perangkat lunak LabVIEW dengan hasil berupa grafik ataupun angka. Dengan ukuran yang tidak terlalu besar alat inipun mudah di bawa kemanapun dan dimanapun. Dengan menggunakan alat yang berbasis virtual instrument tersebut dapat menumpulkan data hasil praktikum dalam hal pengujian alat yang berhubungan dengan elektronika digital dengan baik sesuai dengan ketentuan dari alat tersebut.
\end{abstract}

Kata kunci : decoder, encoder, virtual instrument, NImyRIO.

\begin{abstract}
In the development of measurement technology is essential greetings perform a varety of jobs and collection of data which is objective, that these results. Can have accurate and reliable result. In the measurement of a lot of the tools used greeting trouble something is curtaint measuremend is terms of the effective of the work is not only a lot, but larger than the size of the tool makes difficult to be taken anywhere in the activity because it the development of measurement is helpful works greeting determine the value of the data is to be retrieved. Primarily a tool that is easy to carry anywhere and have the eapability in terms of measurements using digital technology issued by the Nasional Instrument NImyRIO created the tool is programmed to process the lab measurements can be dis played as well into a LabVIEW with the results, in the results in the form of graphs or figures, with a size that is not big tool is easy to carry anywhere, by using a virtual instrument based tool that can collected data form the lab grows in pisting toolls related to digital electronics in accordance with the provisions of the instrument.
\end{abstract}

Keywords : decoder, encoder, viritual instrumrnt and NImyRIO

\section{PENDAHULUAN}

$\mathrm{D}$ alam perkembangan jaman ini pengukuran sangatlah penting terutama pada hasil laporan. Dimana hasil yang diterima dari data tersebut menentukan untuk laporan ataupun pekerjaan yang kita lakukan. Dalam mendapatkan hasil yang akurat dan jelas kita memerlukan alat ukur yang memenuhi standar yang baik dan telah dikalibrasi dari 
badan terkait sehingga dapat dipercaya bahwa hasilnya benar. Untuk melakukan pengukuran banyak sekali alat yang dipergunakan seperti contoh: multimeter, osiloscope, ampermeter, volt meter, ohmmeter, function generator, dan lain-lain. Mungkin sangat merepotkan jika membawa semua alat tersebut dalam hal pekerjaan maupun membuat hasil laporan yang mungkin tempat dan alat yang tidak memadai.

Sistem ini dirancang berdasarkan National Instrument berbasis FPGA myRIO, decoder, encoder yang merupakan contoh dalam pengukuran. Dimana alat tersebut menggunakan sistem terkini dalam melakukan pengukuran maupun pengumpulan data secara komputerisasi dan dapat diatur dalam penggunaannya. Sehingga mempermudah dan sangat meringkas alat-alat yang akan dibawa dalam melakukan pengukuran. Metode yang digunakan dalam perancangan alat adalah ini menggunakan aplikasi LabVIEW sebagai sistem program, yang difungsikan sebagai media penampil dari data yang dibutuhkan dalam pengumpulan data baik berupa angka, grafik, maupun block diagram. Menyesuaikan dengan apa yang dibutuhkan dalam pengukuran namun dalam satu alat yang mempermudah semua jenis pengukuran. Perancangan alat ini dapat digunakan dan diaplikasikan dalam dunia mahasiswa sebagai media pembelajaran dalam praktikum elektronika dasar. Dan dalam dunia industri yang menggunakan sistem elektronika digital.Semoga menjadi inspirasi untuk menciptakan alat lainnya ataupun pengembangannya.

\section{TEORI}

Sebuah instrument adalah alat yang di buat untuk pengambilan data dari suatu modul, ataupun dari sebuah sensor dengan serangkaian pengambilan data dan menampilkannya dalam bentuk instrumen,serta menampilkan dalam bentuk big data yang di menampilkan grafik gambar. Adapun kesesuaian data tersebut di dalamnya terdapat beberapa alat ukur menyesuaikan kebutuhan.
Virtual Instrumet adalah keilmuan yang mepadupadankan suatu sistem perangkan lunak, perangkat keras serta penampilan display yang menjadi satu. Yang di tandai semakin meningkatnya sistem kontrol automasi dan pengukuran.

Field-Programmable Gate Array (FPGA) adalah perangkat semikonduktor yang di rangkai menjadi satu kesatuan dimana komponen tersebut di program untuk dapat melakukan tugas yang berbasis interkoneksi

NI myRio (Reconfigurable Input Output) adalah sebuah perangkan keras (Hardware) buatan National Instrument yang digunakan untuk melakukan perancangan secara nyata, sebuah sistem rekayasa yang kompleks secara lebih cepat dan terjangkau.

Kombinasi dari komponen ini diberikan spesifikasi untuk membuat sirkuit hardware dengan kecepatan input/output yang tinggi dan fleksibel dalam suatu sistem kontrol.

\section{METODOLOGI}

Adapun tahapan yang utama adalah mulai dari perancangan yang di desain baik dan automasi serta memberikan kemudahan sehingga perencanaan dalam pengambilan data ini memiliki manfaat dalam pengukuran terutama dan dalam menjalankan experimen.

\section{HASIL DAN PEMBAHASAN}

\section{Pengujian Decoder Ic 74LS138}

Tabel 1. Pembuktian IC decoder 74LS148.

\begin{tabular}{|c|c|c|c|c|c|c|}
\hline & & & $\sqrt{1}$ & & & PIN OUIPUI \\
\hline O PEM & $A_{0}$ & & & & & $\begin{array}{lllllll}7 & 6 & 5 & 4 & 3 & 2 & 1\end{array}$ \\
\hline PEMBL & $\mathrm{x}$ & $\mathrm{x}$ & & & & $\mathrm{HHHHHHH}$ \\
\hline & $\mathrm{x}$ & $\mathrm{x}$ & $x \times$ & & $\mathrm{x}$ & $\mathrm{HHHHHH}$ \\
\hline & $\mathrm{x}$ & $x$ & $x \quad x$ & $x$ & L & $\mathrm{H} \mathrm{H} \mathrm{H} \mathrm{H} \mathrm{H} \mathrm{H}$ \\
\hline & L & & L L & L & & $\mathrm{HH} \mathrm{HHH}$ \\
\hline & $\mathrm{H}$ & L & L L & L & H & $\mathrm{HHHHHH}$ \\
\hline & L & $\mathrm{H}$ & L L & L & & H H H H \\
\hline & $H$ & $\mathrm{H}$ & L L & L L & & $\mathrm{HHHHLH}$ \\
\hline & L & L & H L & L L & $\mathrm{H}$ & H H H L H H \\
\hline & $\mathrm{H}$ & & H L & L L & H & $\mathrm{HHLHHHF}$ \\
\hline & $\mathrm{L}$ & $\mathrm{H}$ & H L & L L & & \\
\hline & & & H L & & & \\
\hline
\end{tabular}

Saat melakukan pengembangan praktikum tidak hanya menggunakan software saja dalam melakukan pembuktian namun harus ada hardware yang dapat 
memastikan kebenaran dari suatu program ataupun tabel kebenaran.

Berikut adalah tebel hasil pembuktian dari IC 74LS138 yang di program dengan software LabVIEW dan NImyRIO sebagai penghubungnya.

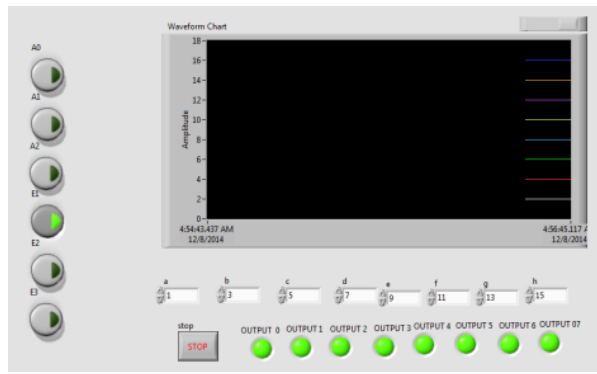

Gambar 1. Pembuktian no 1 Decoder.

Pada saat $E_{1}$ di aktifkan maka grafik yang di munculkan berupa gambar garis lurus yang garis tersebut bernilai di atas dari kolom offset tersebut dan pada semua lampu indikator menyala.

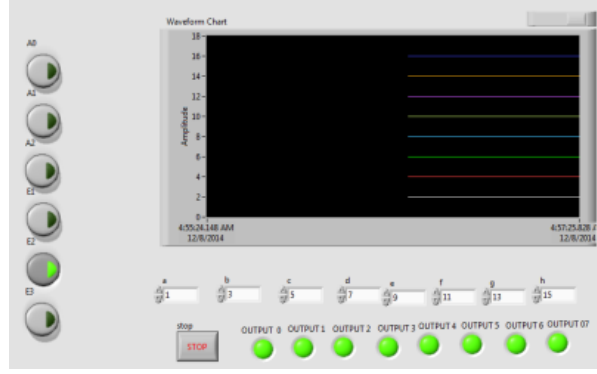

Gambar 2. Pembuktian no 2 Decoder.

Sama halnya dengan pembuktian no 1 pada saat $E_{1}$ di aktifkan maka akan tampil grafik berupa garis lurus yang menandakan aktif high dan di sertai nyalanya semua lampu indikator.

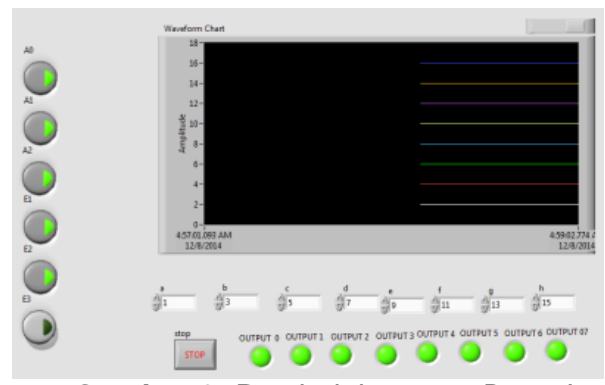

Gambar 3. Pembuktian no 3 Decoder.

Pada saat ini $\mathrm{E}_{3}$ di berikan aktif low dan yang lainnya diberikan aktif high tidak akan merubah grafik atau pun input yang lain di berikan aktif low maka grafik yang di hasilkan pun sama halnya dengan percobaan no 1 dan 2 karena tiga input ini merupakan saklar yang ada pada IC 74LS138 untuk mengaktifkan input yang lainnya.

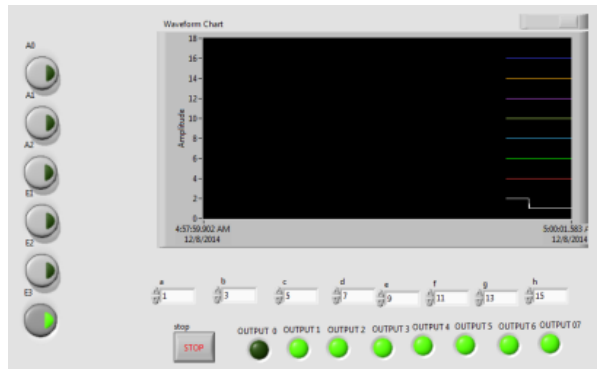

Gambar 4. Pembuktian no 4 Decoder.

Pada saat $\mathrm{E}_{3}$ aktif high dan input yang lainya low maka grafik terjadi pada output 0 yang mengalami penurunan grafik atau aktif low dari nilai 2 ke 1 yang di sertai matinya blampu output 0 .

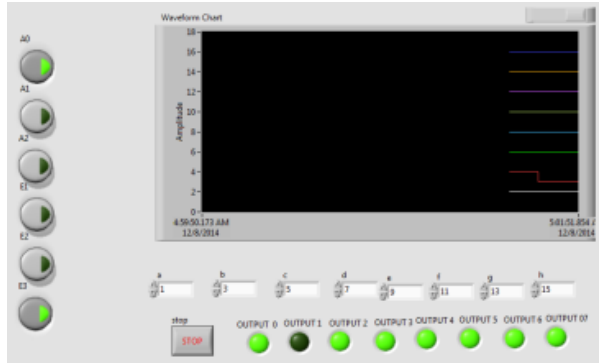

Gambar 5. Pembuktian no 5 Decoder.

Pada saat $E_{3}$ dan $A_{0}$ di berikan aktif high dan yang lain aktif low maka akan terjadi perubahan grafik yang sebelumnya pada output 0 namun sekarang pada output 1 yang mengalami aktif low dan penurunan grafik dari nilai 4 ke 3 di sertai matinya lampu output 1

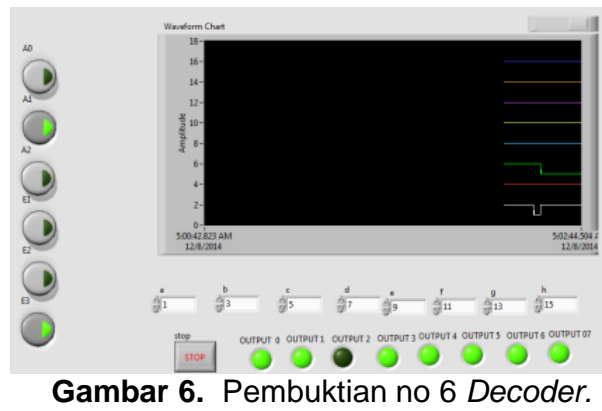

Pada saat $E_{3}$ dan $A_{1}$ di berikan aktif high dan yang lain aktif low maka akan terjadi perubahan grafik dan penurunan grafik dari nilai 6 ke 5 di sertai matinya lampu output 2 


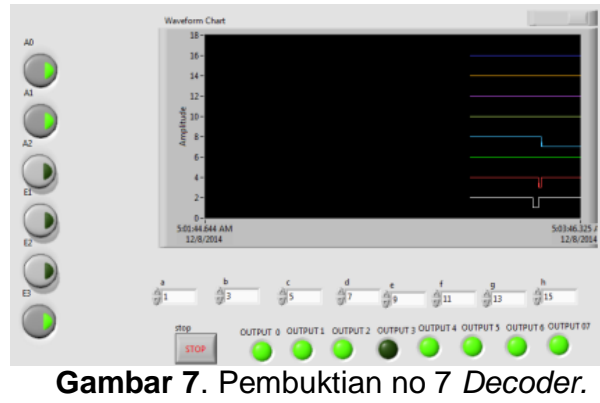

Pada saat $E_{3}, A_{0}$ dan $A_{1}$ di berikan aktif high dan yang lain aktif low maka akan terjadi erubahan grafik serta penurunan grafik dari nilai 8 ke 7 di sertai matinya lampu output 3

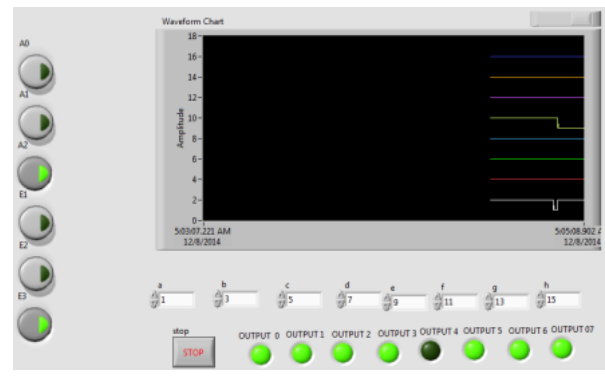

Gambar 8. Pembuktian no 8 Decoder.

Pada saat $E_{3}$ dan $A_{2}$ di berikan aktif high dan yang lain aktif low maka akan terjadi perubahan grafik dan penurunan grafik dari nilai $10 \mathrm{ke}$ di sertai matinya lampu output 4

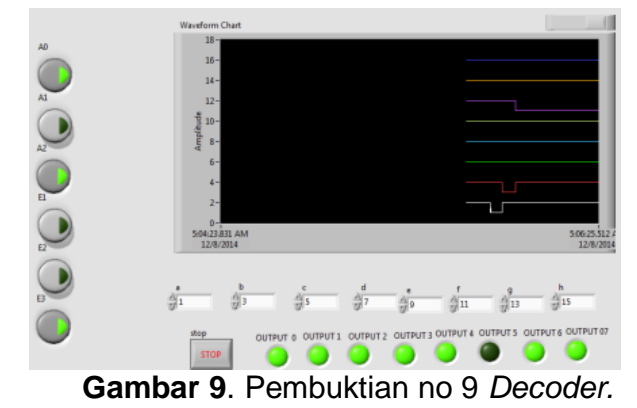

Pada saat $E_{3}, A_{0}$ dan $A_{2}$ di berikan aktif high dan yang lain aktif low maka akan terjadi perubahan grafik serta penurunan grafik dari nilai 12 ke 11 di sertai matinya lampu output 5

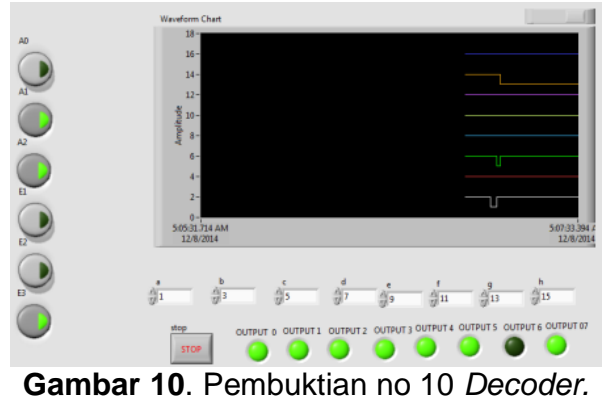

Pada saat $E_{3}, A_{1}$ dan $A_{2}$ di berikan aktif high dan yang lain aktif low maka akan terjadi perubahan grafik serta penurunan grafik dari nilai 14 ke 13 disertai matinya lampu output 6

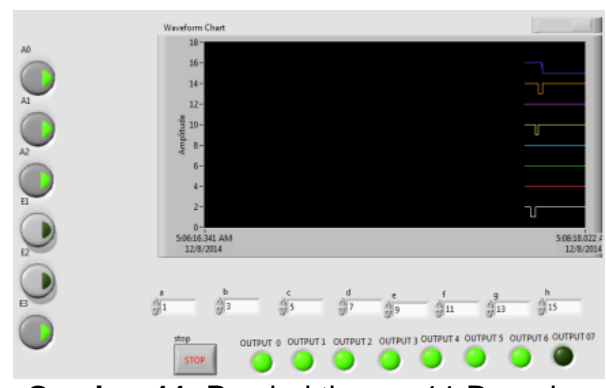

Gambar 11. Pembuktian no 11 Decoder.

Pada saat $E_{3}, A_{1}, A_{2}$ dan $A_{3}$ di berikan aktif high dan yang lain aktif low maka akan terjadi perubahan grafik serta penurunan grafik dari nilai 16 ke 15 disertai matinya lampu output 7

Dari hasil pembuktian tersebut dapat di nyatakan bahwa IC 74LS138 sesuai dengan tabel kebenaran yang ada untuk pembuktian lanjutan menggunakan sistim yang di program dari LabVIEW yang berjalan secara terus menerus sesuai dengan tabel kebenaran.

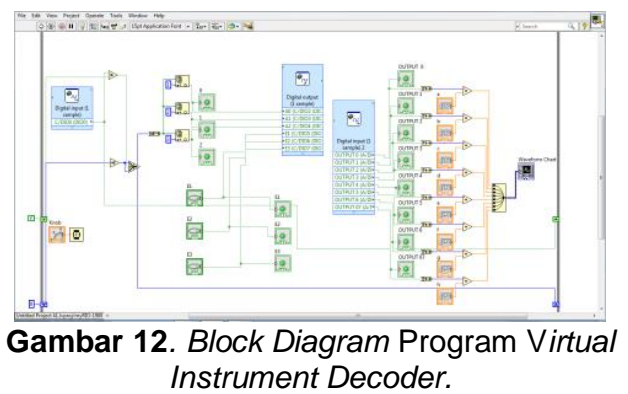




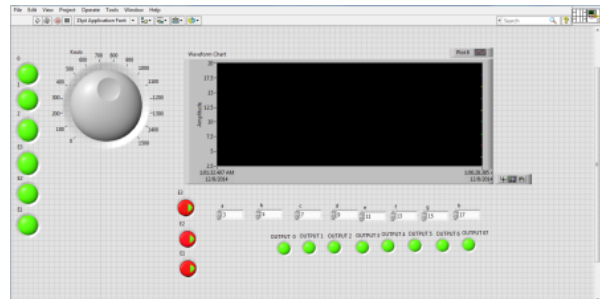

Gambar 13. Front Panel Virtual Instrument Osiloscope Decoder.

Program virtual instrument LabVIEW 2014 yang dijalankan dalam melakukan penampilan grafik maupun data yang bisa di export ke Microsoft office excel secara langsung sambil berjalannya program sehingga dapatlah data yang mengacu pada tabel kebenaran dari IC 74LS138. Hal ini merupakan pengembangan praktek elektronika digital dalam penampilan grafik maupun data.

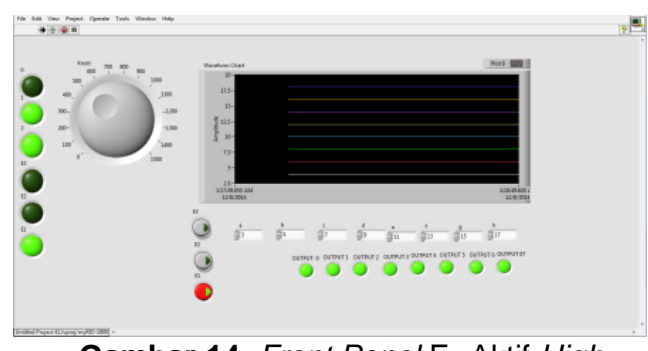

Gambar 14. Front Panel $\mathrm{E}_{1}$ Aktif High.

Menyesuaikan dengan tabel kebenaran fungsi IC 74LS138 bahwa ketika $E_{1}$ di aktifkan maka grafik pada gambar sejajar garis lurus yang berarti on serta lampu indikator menyala

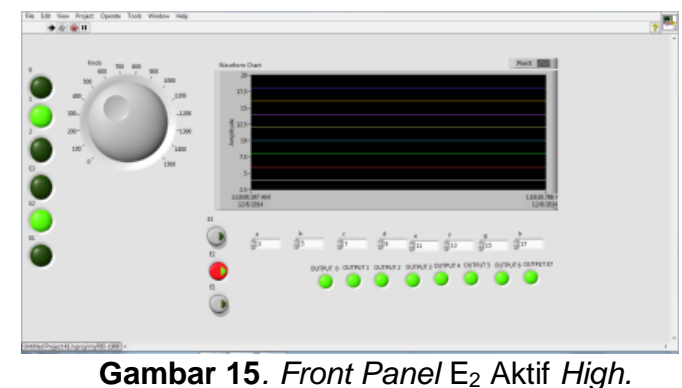

Sama halnya dengan $E_{1}$ jika $E_{2}$ aktif high akan menghasilkan grafik yang sama dengan apa yang telah di buktikan pada gambar di atas.

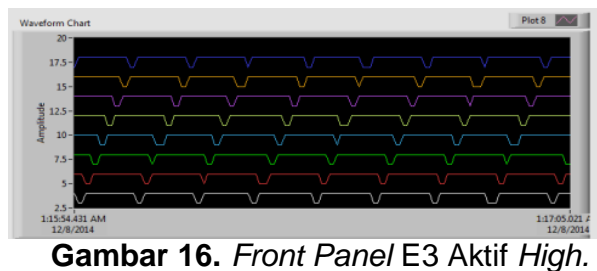

Dengan menggunakan rangkaian counter di dalam rangkaian yang dapat membangkitkan clock pulse terhadap IC dan di buat berjalan secara terus menerus dengan $\mathrm{DI} / \mathrm{O}$ yang terhubung langsung dengan myRIO maka akan dapat di hasilkan gambar dan visual sesuai tabel kebenaran yaitu aktif low mulai dari output 0 hingga output 7 secara bergantian.

\section{Pengujian Encoder ic 74LS148}

Tabel 2. Pembuktian IC encoder 74LS138.

\begin{tabular}{|c|c|c|c|c|c|c|c|}
\hline & & & V IN & & & & IN OUTPUT \\
\hline NOP & & & & & & 76 & \begin{tabular}{|l|l|l|l|l|}
5 & 4 & 3 & 2 & 1
\end{tabular} \\
\hline PEMBUKTIAN 1 & $x$ & $x$ & $\mathrm{x}$ & $H X$ & & & $\mathrm{HHHHH}$ \\
\hline PEMBUKTIAN 2 & $x$ & $x$ & $\mathrm{x}$ & $x H$ & & $\mathrm{H} \mathrm{H}$ & $\mathrm{HHHHH}$ \\
\hline PEMBUKTIAN 3 & $x$ & $\mathrm{x}$ & $x$ & $x \times$ & & $\mathrm{H} \mathrm{H}$ & $\mathrm{HHHHH}$ \\
\hline PEMBUKTIAN 4 & $\mathrm{~L}$ & L & L & L & & $\mathrm{H} \mathrm{H}$ & $\mathrm{HHHHH}$ \\
\hline PEMBUKTIAN 5 & $\mathrm{H}$ & L & L & L & & $\mathrm{H} \mathrm{H}$ & $\mathrm{HHH}$ \\
\hline PEME & L & $\mathrm{H}$ & L & L & & $\mathrm{H} \mathrm{H}$ & $\mathrm{LH}$ \\
\hline PEMBUKTIAN 7 & $\mathrm{H}$ & H & L & L & & $\mathrm{H} \mathrm{H}$ & $\mathrm{HH} \mathrm{LH}$ \\
\hline PEMBUKTIAN 8 & L & L & H & L & & $\mathrm{H} \mathrm{H}$ & $\mathrm{H} L \mathrm{H} H \mathrm{H}$ \\
\hline PEMBUKTIAN 9 & $\mathrm{H}$ & L & H & L & & $\mathrm{H} \mathrm{H}$ & $\mathrm{LHHHH}$ \\
\hline PEMBUKTIAN 10 & L & $\mathrm{H}$ & $\mathrm{H}$ & $L$ & & H L & $\mathrm{HHHHH}$ \\
\hline PEMBUKTIAN 11 & $\mathrm{H}$ & H & & & & & $\mathrm{HH} \mathrm{HH}$ \\
\hline
\end{tabular}

Sama hal nya dengan decoder, encoder pun dapat di realisasikan dengan melakukan praktek langsung menggunakan IC yang mengacu pada tabel kebenaran yang ada pada IC 74LS148 encoder.

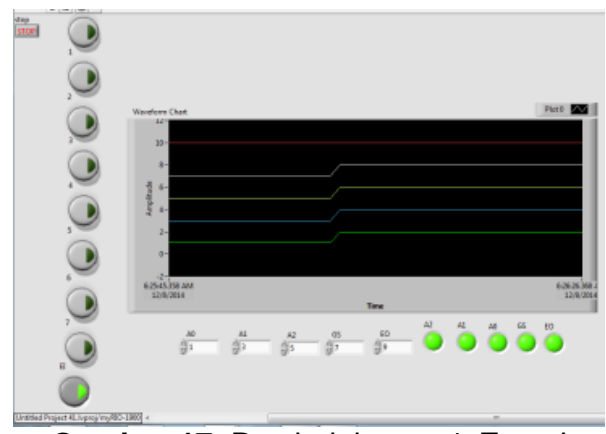

Gambar 17. Pembuktian no 1 Encoder.

Pada saat El aktif high maka grafik pada gambar akan menunjukan kenaikan garis yang menandakan aktif dan disertai oleh nyalanya semua lampu indikator output. 


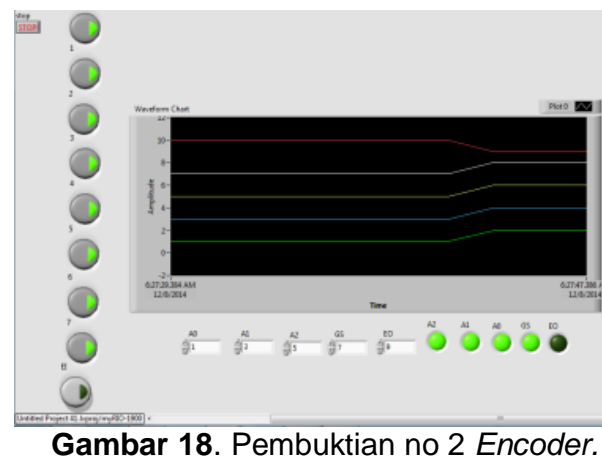

Pada saat input 0 sampai 7 mendapatkan aktif high dan El mendapat aktif low maka grafik tersebut menunjukan aktif high pada output A2, A1, A0, dan GS sedangkan output EO mendapat aktif low dengan lampu indikator menyala pada output A2, A1, A0, GS sedangkan lampu EO mati.

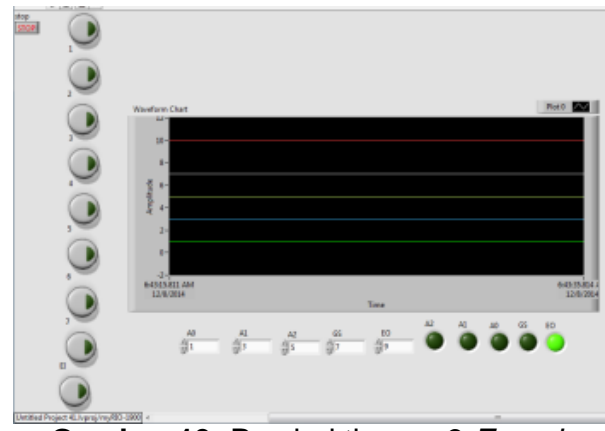

Gambar 19. Pembuktian no 3 Encoder.

Pada saat EI dan input 7 mendapatkan aktif low maka dalam tampilan grafik pada garis A2, A1, A0, dan GS mendapatkan aktif low dan EO mendapatkan aktif high dengan ditandai menyalanya lampu EO.

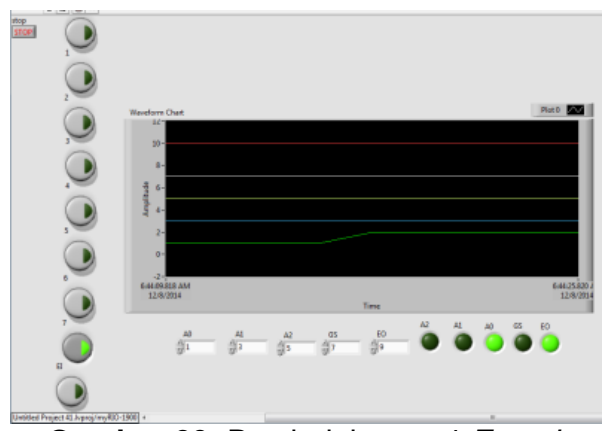

Gambar 20. Pembuktian no 4 Encoder.

Pada saat El, dan input 6 mendapatkan aktif low sedangkan pahda input 7 mendapatkan aktif high maka hasil dari grafik tersebut adalah aktif high pada A0 dan EO

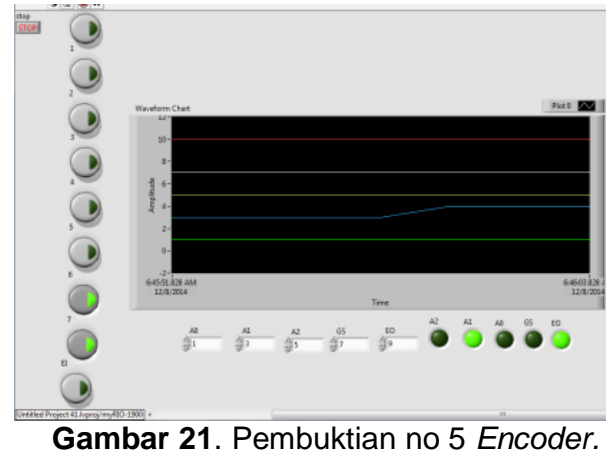

Pada saat input 6 dan 7 mendapatkan aktif high maka grafik yang di tunjukan bahwa A1 dan EO mendapatkan aktif high bersamanya menyala lampu indikator.

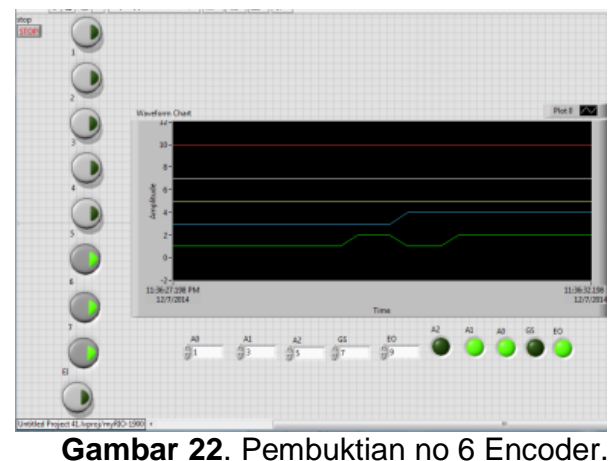

Pada saat input 5, 6 dan 7 mendapatkan aktif high maka grafik yang di tunjukan bahwa A1,A0 dan EO mendapatkan aktif high bersamanya menyala lampu indicator

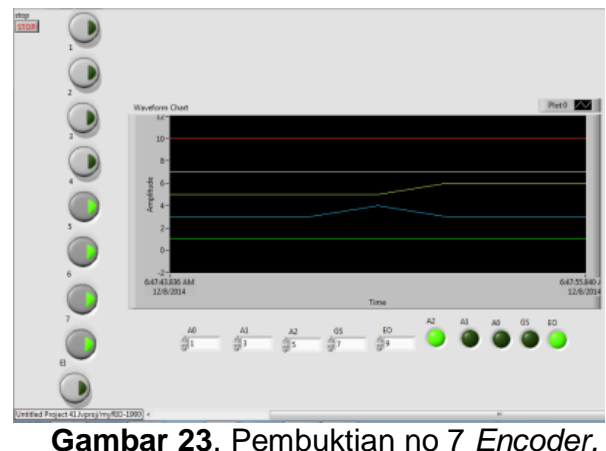

Pada saat input 4, 5, 6 dan 7 mendapatkan aktif high maka grafik yang di tunjukan bahwa A2 dan EO mendapatkan aktif high bersamanya menyala lampu indikator. 


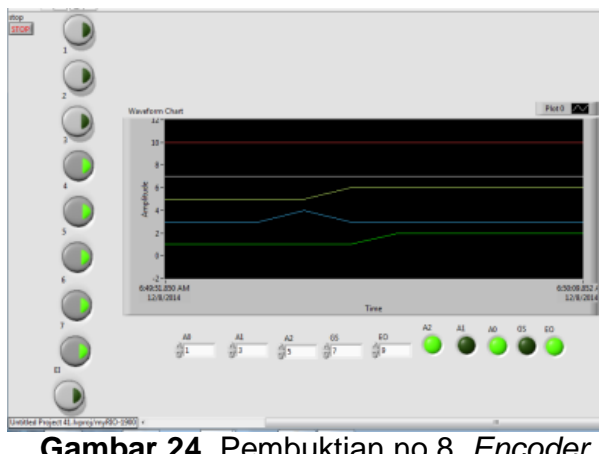

Pada saat input 3, 4, 5, 6 dan 7 mendapatkan aktif high maka grafik yang di tunjukan bahwa A2, A0 dan EO mendapatkan aktif high bersamanya menyala lampu indikator.

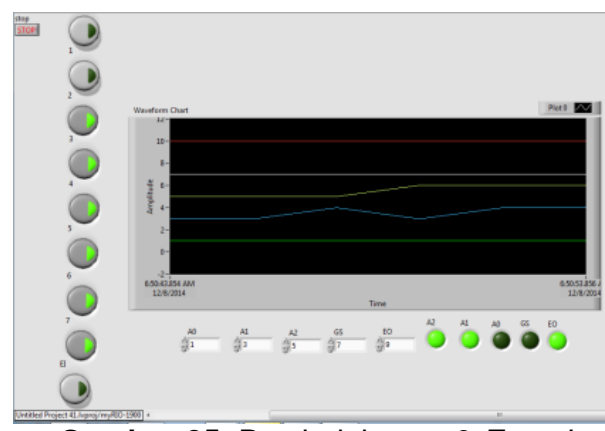

Gambar 25. Pembuktian no 9 Encoder.

Pada saat input 2, 3, 4, 5, 6 dan 7 mendapatkan aktif high maka grafik yang di tunjukan bahwa A2, A1 dan EO mendapatkan aktif high bersamanya menyala lampu indicator

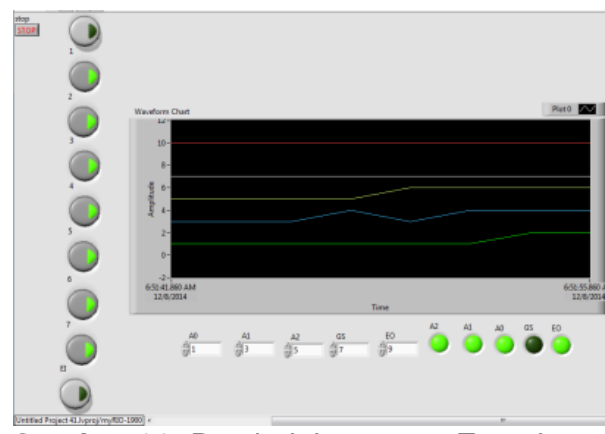

Gambar 26. Pembuktian no 10 Encoder.

Pada saat input 1,2, 3, 4, 5, 6 dan 7 mendapatkan aktif high maka grafik yang di tunjukan bahwa A2, A1,A0 dan EO mendapatkan aktif high bersamanya menyala lampu indikator

Dari hasil pembuktian tersebut dapat di nyatakan bahwa IC 74LS148 sesuai dengan tabel kebenaran yang ada untuk pembuktian lanjutan menggunakan sistim yang di program dari LabVIEW yang berjalan secara terus menerus sesuai dengan tabel kebenaran.

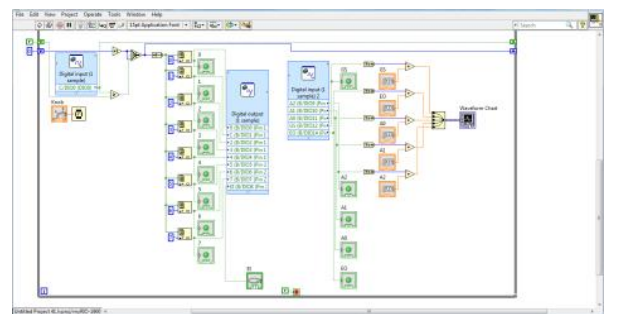

Gambar 27. Block Diagram Program Virtual Instrument Encoder.

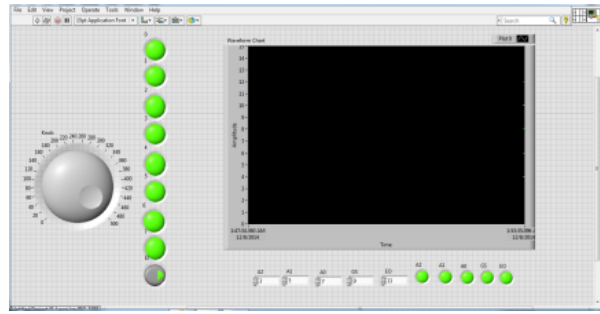

Gambar 28. Front Panel Virtual Instrument Osiloscope Encoder.

Program virtual instrument LabVIEW 2014 yang di jalankan dalam melakukan penampilan grafik maupun data yang bisa di export ke Microsoft office excel secara langsung sambil berjalannya program sehingga dapatlah data yang mengacu pada tabel kebenaran dari IC 74LS148. Hal ini merupakan pengembangan praktek elektronika digital dalam penampilan grafik maupun data.

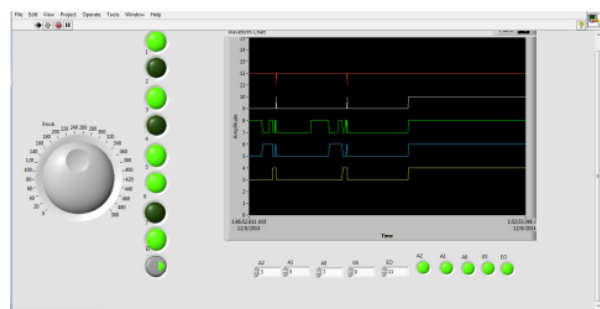

Gambar 29. Front Panel Aktif High Ei.

Pada saat El mendapatkan aktif high maka akan mengaktifkan semua output dan menyalakan lampu indikator.

Dari hasil penelitian pengembangan praktikum decoder dan encoder menggunakan virtual instrument di dapatkan kesimpulan.

Pengujian terhadap sebuah IC dengan cara manual memakan waktu dan tidak praktis. Untuk mengatasi hal tersebut maka 
di buat sebuah penguji IC dengan bantuan PC.

Rancangan alat penguji IC decoder dan encoder telah dapat di wujudkan dengan menggunakan perangkat FPGA.

Dengan memasukkan kombinasi kemungkinan dari masukan gerbang IC, serta membandingkan hasil keluaran tersebut dengan tabel kebenaran dari jenis IC decoder dan encoder, maka baik atau buruknya IC tersebut dapat di ketahui

Perangkat system pengujian dengan menggunakan FPGA $\mathrm{NI}$ myRIO di serta terprogram dengan LabVIEW IC digital sangat potensial di kembangkan karena banyak keuntungan dan kemudahan yang di dapatkan bagi mahasiswa khususnya dalam praktikum elektronika digital.

\section{KESIMPULAN}

Penggunaan alat ukur bervariasi dari berbagai merk dan tipe. Pengambilan data pengukuran menggunakan komponen dengan ukuran yang berbeda. Pemakaian perangkat keras untuk pengukuran menggunakan NI MyDAQ. Setelah melakukan pengukuran dan perhitungan ternyata terdapat selisih, dikarenakan terdapat beberapa faktor diantaranya :

1. Kurang cermat dalam pembacaan dari hasil pengukuran.

2. Karena komponen yang digunakan tidak ideal.

3. Tegangan sebagai sumber pengukuran berubah ubah/tidak stabil.

4. Penempatan komponen dan penyolderan kurang maksimal.

Untuk menghindari hal-hal tersebut harus dibutuhkan kecermatan dan ketelitian serta alat dan komponen yang mendekati ideal, sebab untuk menemukan suatu komponen ideal kurang tersedia dipasaran.

\section{UCAPAN TERIMAKASIH}

Penyusun mengetahui tidak ada yang sempurna dalam menciptakan suatu bentuk penelitian tampa bantuan dari pembimbing, rekan, orang tua. Dan segala hambatan maupun kesulitan yang dialami merupakan bentuk pembelajaran dan introspeksi diri saya pribadi. Pada penelitian ini saya pribadi selaku penyusun ingin mengucapkan terima kasih kepada:
1. Tuhan Yang Maha Esa yang selalu memberikan rahmatanlil alaminnya kepada kami sehingga penelitian ini dapat selesai;

2. Bapak Kaprodi Teknik Elektro serta pembimbing kami, Bapak Syaiful Bakhri, S.T., M.Eng.Sc., Ph.D.,

3. Orang tua yang selalu mensuport dari awal hingga selsesainya penelitian ini tak putus pula doa yang di panjatkan demi kelancaran selesainya penelitian ini.

\section{DAFTAR PUSTAKA}

[1] Boylestad, Robert, and Nashelsky, Louis. 1992. Electronic Devices and Circuit Theory.

[2] Elektronika, Dunia., 2007., catu daya. http://duniaelektronika.blogspot.com/20 07/09/catu-daya.html.

[3] National instruments, LabVIEW system Design Software online 2013. http://www.ni.com/labview.

[4] Carter, B., \& Brown, T. (2001). Handbook of Operational Amplifier Applications. Texas: Texas Instruments.

[5] Rakhman, Alief. 08/2012. "labviewsoftware". 